International Journal of Economics, Business and Accounting Research (IJEBAR)

Peer Reviewed - International Journal

Vol-4, Issue-2, 2020 (IJEBAR)

E-ISSN: 2614-1280 P-ISSN 2622-4771

https://jurnal.stie-aas.ac.id/index.php/IJEBAR

\title{
THE EFFECT OF CUSTOMER VALUE AND CUSTOMER TRUST ON SATISFACTION AND CUSTOMER LOYALTY PT SAMATOR GAS INDUSTRI SAMARINDA SEBERANG
}

\author{
Indra Permana Kusuma Putra1 Syarifah Hudayah2 Gusti Noorlitaria Achmad3 \\ 1,2,3aculty of Economics and Business Mulawarman University \\ Email: indramanajemen@gmail.com1),syarifah.hudayah@feb.unmul.ac.id2) \\ gusti.noorlitaria.achmad@feb.unmul.ac.id3)
}

\begin{abstract}
In this study involving consumers PT Samator Gas Industri Samarinda Seberang. In this study, a sample of 120 respondents was used to see customer satisfaction and customer loyalty. The data analysis used by the author is the Structural Equation Model (SEM). Hypothesis testing is done by multivariate analysis carried out through the SmartPLS program. Data analysis through partial Least Square (PLS) is done through two stages, namely: First, Assessing the outer model or measurement model. Second, assess the inner model or structural model. The results showed that Customer value had a significant positive effect on customer satisfaction, Customer trust had a significant positive effect on customer satisfaction, Customer value had a significant positive effect on loyalty, Customer trust had a significant positive effect on loyalty, Satisfaction had a nonsignificant positive effect on loyalty on PT Samator Gas Samarinda Industry Opposite.
\end{abstract}

Keywords: $\quad$ Customer value, Customer trust, Customer Satisfaction, Customer loyalty.

\section{Introduction}

Based on the performance of PT Samator Gas Industri Samarinda Seberang has a marketing scope of products covering the areas of Samarinda, Tenggarong, Balikpapan, Bontang, Sangatta, Trakan, Tanjung Selor Melak Kota Bangun and senoni, the management feels concerned about competition which has increased significantly due to the high level of competition between companies. This can be seen in the growing number of competitors and product verification that could pose a threat in the future for this company, companies that have the same core business as PT Samator Gas Industri Samarinda Seberang, including PT Murni Gas Raya, PT Surya Biru Murni Acetylene and PT Linde.

Based on the level of competition that is the main focus of PT Samator Gas Industri Samarinda Seberang, the thing to do is to maintain the level of customer satisfaction to refer directly to the customer loyalty expected by the company. Consumers who are not satisfied then decide not to use services or product purchases at the company, so they also complain of dissatisfaction with other consumers who ultimately shape the perception of others about the products or services of PT Samator Gas Industri Samarinda Seberang. Consumers who are satisfied with the services or products provided will encourage others to use the company, while consumers who are less satisfied only encourage others to use other companies.

Based on the preliminary survey, there are still complaints from consumers and if this is not known and is not done quickly by the management it will cause customer exit and

International Journal of Economics, Business and Accounting Research (IJEBAR) Page 151 
International Journal of Economics, Business and Accounting Research (IJEBAR)

Peer Reviewed - International Journal

Vol-4, Issue-2, 2020 (IJEBAR)

E-ISSN: 2614-1280 P-ISSN 2622-4771

https://jurnal.stie-aas.ac.id/index.php/IJEBAR

customer voice, therefore it is necessary to measure the level of satisfaction to determine whether the customer is satisfied or not to the service has been obtained, if the customer is dissatisfied, it must immediately know the causes and make corrections or improvements to eliminate the dissatisfaction. If the customer is satisfied it is necessary to maintain that the customer remains a customer at PT Samator Gas Industri Samarinda Seberang and does not switch to other companies (customer retention), in addition to measuring the level of customer satisfaction a strategy is also made to create customer loyalty at PT Samator Gas Industri Samarinda Seberang.

\section{Foundation of Theory and Development of Hypotheses}

\section{The relationship between customer value and satisfaction}

Value can be felt by customers if they have used the product purchased because value is an experience that is felt by the customer. The emotional impression that is felt by the customer is an obligation for the producer to create a positive psychological impression, especially for users who intensively use the example of motorcycle taxi drivers who use motorcycles to support their work. Hurriyarti (2008: 111) business carried out by companies is to deliver customer value and the basic mission of a business company is no longer in the form of profit, but rather the creation and addition of value for customers while profit is a consequence of giving customer value.

The purpose of value creation is to create customer satisfaction. Kotler \& Keller (2009: 138) Customer Satisfaction is a feeling of pleasure or disappointment someone who arises because of comparing the perceived real performance of the product, compared to customer expectations before the use of the product. The main key in creating satisfaction cannot be separated from the name of customer expectations and impressions felt by customers, so that producers who understand customer satisfaction will try to create offers that are able to provide expectations and positive impressions of a product, by integrating Customer value as the main factor in the offer. The higher the Customer value, the satisfaction felt by the customer will also be higher. Mardikawati (2013) that there is a positive influence between Customer value on Customer Satisfaction.

\section{The relationship between customer value and loyalty}

Customer value has a very close relationship with customer loyalty. The application of high customer value will create superior customer value. Furthermore, superior customer value will increase the satisfaction of the target market which will ultimately give a positive response in the form of more and more customers using and loyal to the product, due to the higher perceived value of the customer than the value offered by its competitors

Relationship between customer value and customer loyalty Robinette (2001: 9), namely: success ang growth are shown to be dependent on the link among values, profits, and customer loyalty. Customer success and growth will depend on creating value, profit and loyalty from customers. The creation of high customer value will foster emotional bonds and positive responses between customers and companies in building relationships. Relationships that are established without emotion become a mechanical activity and make customers have no real reason to stay. To increase loyalty the company must increase the satisfaction of each customer and maintain that level of satisfaction in the long run.

Griffin (2003: 133) that to get loyal customers the company must provide customer value continuously, improve, improve, or even change products or services to increase profits for customers. Therefore to increase satisfaction, companies must add value that can get them what they paid for or more than they expected so that they can survive and lead to repeat purchases, recommendations and an increasing proportion of spending.

International Journal of Economics, Business and Accounting Research (IJEBAR) Page 152 
International Journal of Economics, Business and Accounting Research (IJEBAR)

Peer Reviewed - International Journal

Vol-4, Issue-2, 2020 (IJEBAR)

E-ISSN: 2614-1280 P-ISSN 2622-4771

https://jurnal.stie-aas.ac.id/index.php/IJEBAR

\section{The relationship between customer trust and satisfaction}

Morgan \& Hunt (2014) defines trust as a condition when one party involved in the exchange process believes in the reliability and integrity of the other party. Moorman et al. (2011) that trust is a willingness or willingness to rely on colleagues involved in exchanges that are believed. Willingness is the result of a belief that the parties involved in the exchange will provide consistent quality, honesty, responsibility, light-heartedness and good heart. This belief will create a close relationship between the parties involved in the exchange (Suhardi, 2006). Moorman et al. (2011) defines trust as a willingness to depend on other parties who have been trusted. Trust contains two different aspects, namely credibility which refers to the belief that the other party has expertise in carrying out their duties and the sincerity of the other party that he has the sincerity to carry out as agreed. This definition indicates that trust is a fundamental component of marketing strategies in creating true relationships with consumers. The company that operates builds a cooperative relationship with its customers as one of the competitive strategies. With a long-term cooperative relationship, companies can work more effectively by saving transaction costs and increasing competitiveness. Such cooperative relationships are usually characterized by high trust (Morgan \& Hunt, 2014). Costabile (2004) defines trust as a perception of reliability from the point of view of consumers based on experience, or more on sequences of transactions or interactions characterized by meeting expectations for product performance and satisfaction.

\section{The relationship between customer trust and loyalty}

Islam (2010: 135) states that it is necessary to look for veriabel that can guarantee the longterm commitment of consumers to a single provider. One of these variables is trust. Trust is a strong driver of Consumer retention to build relationship commitment and customer loyalty, trust is found as an important factor and also an important variable in relationships.

In the business environment, to build and maintain long-term relationships, trust has been found to be a very important factor. Trust can reduce the risk of using services, because it can be considered as a consequence of a positive evaluation of service and customer loyalty. In addition, that consumer confidence in the company is an attitude of loyalty for consumers who are relational oriented, trust and commitment are the key antecedents of loyalty.

Morgan \& Hunt (2014) revealed that the relationship behavior that occurs between a company and its partners is largely determined by trust and commitment, so that it can be expected that trust will have a positive relationship with re-intention and loyalty.

\section{The relationship between satisfaction with customer loyalty}

In this era of increasingly fierce competition, one way to get loyal customers is to satisfy the needs of consumers consistently from time to time. Many ways that companies can use to satisfy consumer needs (Ferrinadewi, 2005). Customer satisfaction is the attitude, assessment and emotional response shown by consumers after the purchase / consumption process that comes from the comparison of his impression of the actual performance of a product and his expectations and evaluation of the experience of consuming a product or service (Wilkie, 1994).

Wilkie (1994) states that there are five elements of customer satisfaction, namely: 1) expectations, which are expectations built by consumers during the pre-purchase phase; 2) performance, namely how consumers realize and accept the performance of the product; 3 ) comparison, which is a comparison made by consumers after consuming the product; 4)

International Journal of Economics, Business and Accounting Research (IJEBAR) Page 153 
International Journal of Economics, Business and Accounting Research (IJEBAR)

Peer Reviewed - International Journal

Vol-4, Issue-2, 2020 (IJEBAR)

E-ISSN: 2614-1280 P-ISSN 2622-4771

https://jurnal.stie-aas.ac.id/index.php/IJEBAR

confirmation or disconfirmation, is the result of comparison that will produce confirmation of expectation or produce disconfirmation of expectation 5) disrepancy, indicating how the difference between the level of performance with expectations. When actual performance is below expectations, a wider gap will result in a high level of dissatisfaction. Product loyalty is a consistent consumer preference to make purchases on the same product on specific products or certain service categories (Schiffman \& Kanuk, 2004: 102).

Product loyalty has a close relationship with customer satisfaction. Where product loyalty is directly affected by satisfaction with products that have been accumulated in a certain period of time as per the perception of customer trust (Mowen \& Minor, 2002). The level of customer satisfaction will affect the degree of consumer product loyalty. Because one of the factors that influence product loyalty is customer satisfaction (Schiffman \& Kanuk, 2004: 123).

Consumers in meeting their needs and desires, will buy products with certain products. Before making a purchase, consumers will develop an expectation or belief about what the product expects from a product where the expectation is a quality standard that will be compared with the function or customer trust that consumers actually feel. Hopes that are formed are still in the mind (cognitive) of consumers. This expectation will be continued by buying / consuming products.

During consuming the product, consumers will feel the actual product function (actual performance). Where the actual product function is felt by consumers is the consumer's perception of the customer trust. This perception is a representation of what is believed / believed by consumers, which is formed in the cognitive so that it will eventually develop cognitive loyalty in consumers. After consuming the product, consumers will compare their expectations with the product's function.

Through comparison (comparison) will be obtained results whether consumers will be satisfied or not satisfied with the products they consume. Satisfaction indicates a positive attitude and feeling towards the product, if the consumer has a positive attitude towards the product, then the consumer will develop affective loyalty. Satisfied consumers will intend to use the same product in the future (conative loyalty).

Repurchasing on the same product will show customer loyalty to the product (Sumarwan, 2003: 76). But in product loyalty, repeated purchases of the product are influenced by loyalty to the product.

Loyalty to products involves the function of psychological processes which show that when consumers are loyal to certain products, consumers will actively choose products, engage with products and develop positive attitudes towards products (Kumar, 2002).

Sumarwan (2003: 88) also added that loyalty will lead to the emergence of commitment to the product, namely the emotional and psychological closeness of a consumer to the product of a product. But it must be remembered, that product loyalty is not always caused by customer satisfaction. As a result, there is an asymmetrical relationship between loyalty and satisfaction (Gommans, 2001), the relationship between product loyalty and customer satisfaction is asymmetrical where people who are loyal to a product are certainly satisfied but customer satisfaction does not always lead to product loyalty. From the explanation above it can be concluded that customer satisfaction is one of the factors that influence product loyalty to consumers.

\section{Research Methods}

The population in this study is consumers of PT Samator Gas Industri Samarinda Seberang. This study uses a sampling technique in this study is Nonprobability Sampling. Sample requirements in this study were respondents who used the services of PT Samator Gas

International Journal of Economics, Business and Accounting Research (IJEBAR) Page 154 
International Journal of Economics, Business and Accounting Research (IJEBAR)

Peer Reviewed - International Journal

Vol-4, Issue-2, 2020 (IJEBAR)

E-ISSN: 2614-1280 P-ISSN 2622-4771

https://jurnal.stie-aas.ac.id/index.php/IJEBAR

Industri Samarinda Seberang, respondents in this study were the relations of PT Samator Gas Industri Samarinda Seberang.

Then the number of samples used in this study were 120 respondents, to measure customer loyalty satisfaction of PT Samator Gas Industri Samarinda Seberang in this study focused on consumers who use company products more than 2 times and included in the corporate category instead of individuals, in this study questionnaire filled by the procurement of goods and services in each company, the reason for choosing the procurement of goods and services is because the division knows the company's needs.

In this study data analysis uses the Partial Least Square (PLS) approach. PLS is a Structural Equation Modeling (SEM) equation model based on components or variants. PLS is an alternative approach that shifts from a covariant-based SEM approach to variantbased. Covariance-based SEM generally tests causality / theory while PLS is more predictive model. PLS is a powerful analysis method

\section{Discussion}

\section{Research Model Using Partial Least Square}

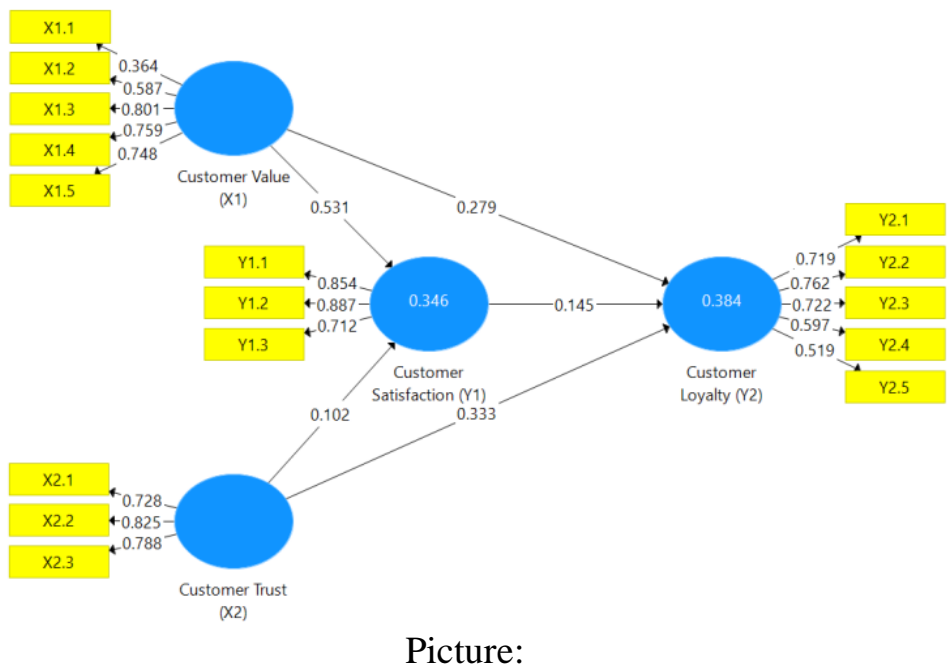

Research Models Before Elimination

In the research model the loading factor requirement above 0.50 reflects the loading factor that describes the variable. In the initial research model it can be seen that there is a construct in the loading factor variable which has a value below 0.5. Based on this criterion, indicators whose loading values are less than 0.50 are eliminated from the analysis. Indicators that are eliminated in the initial research model are indicators for customer value variables, which are the first indicator (X1.1) so that a new research model is obtained with the following picture:

International Journal of Economics, Business and Accounting Research (IJEBAR) Page 155 
International Journal of Economics, Business and Accounting Research (IJEBAR)

Peer Reviewed - International Journal

Vol-4, Issue-2, 2020 (IJEBAR)

E-ISSN: 2614-1280 P-ISSN 2622-4771

https://jurnal.stie-aas.ac.id/index.php/IJEBAR

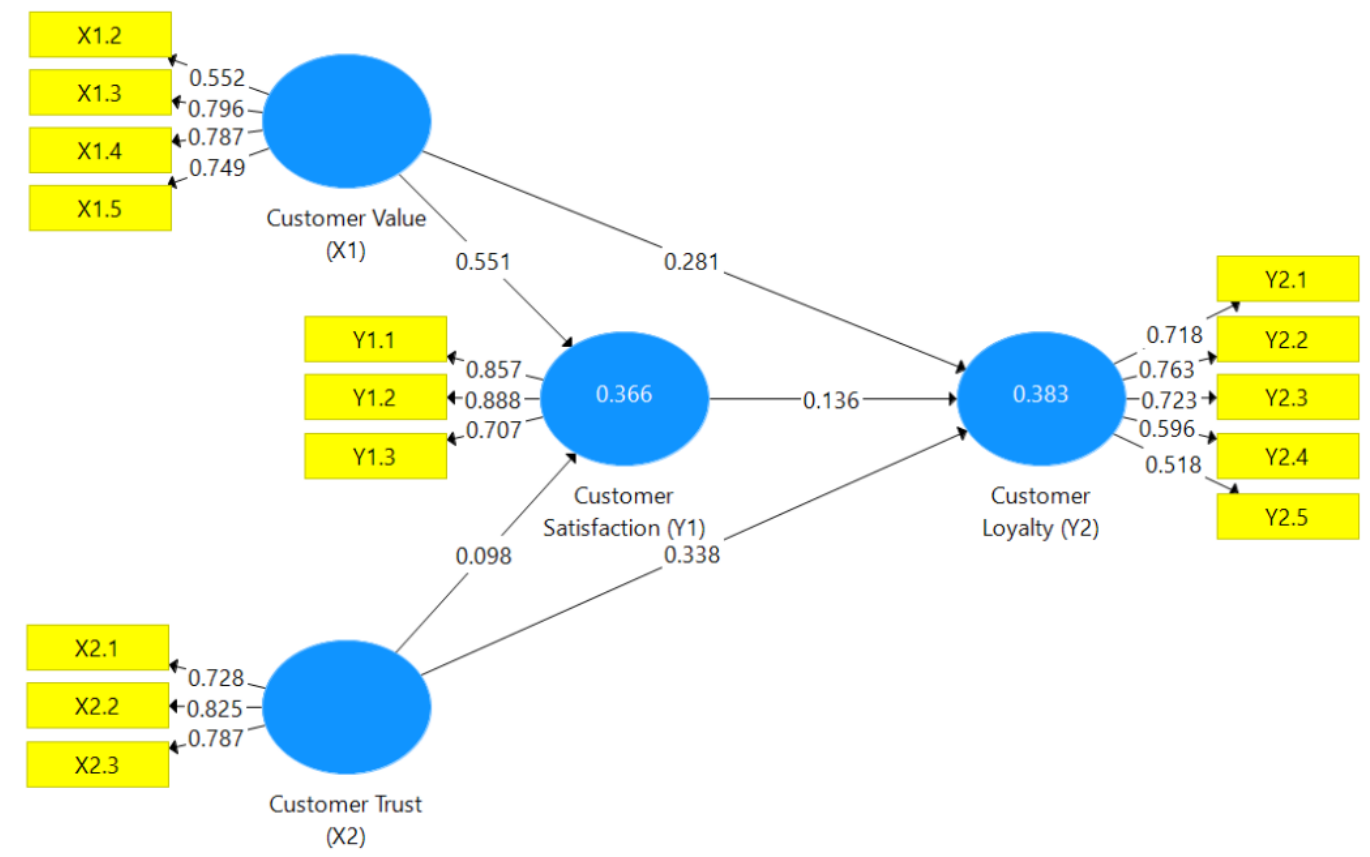

Picture:

Research Model After Elimination

Based on the picture it appears that all loading factors are 0.50 so that research can proceed to analyze the measurement model or outer model and the structural or inner model.

\section{Goodness of Fit Model Check}

The goodness of fit of the PLS model is measured through the Q-square predictive relevance value, to measure how well the observed value is generated by the model and also the estimated parameters. Goodness of fit testing uses predictive-relevance (Q2) value. $\mathrm{R} 2$ values of each endogenous variable in this study are as follows:

Table: Nilai R-Square

\begin{tabular}{|c|c|}
\hline Endogen Variable & $\mathrm{R}_{2}$ \\
\hline Customer satisfaction & $0.366 / 36,60 \%$ \\
\hline Customer loyalty & $0.383 / 38,30 \%$ \\
\hline
\end{tabular}

Source: Data processing with PLS, 2020.

\section{T-test testing}

Testing the inner model or structural model is done to see the relationship between the constructs of the research model. The basis used in testing hypotheses is the value contained in the output result for inner weight. The results of the analysis and hypothesis testing can be seen in the table:

International Journal of Economics, Business and Accounting Research (IJEBAR) Page 156 
International Journal of Economics, Business and Accounting Research (IJEBAR)

Peer Reviewed - International Journal

Vol-4, Issue-2, 2020 (IJEBAR)

E-ISSN: 2614-1280 P-ISSN 2622-4771

https://jurnal.stie-aas.ac.id/index.php/IJEBAR

Table: Result For Inner Weights

\begin{tabular}{|l|c|c|c|}
\hline \multicolumn{1}{|c|}{ Construct } & $\begin{array}{c}\text { Original } \\
\text { Sample }\end{array}$ & P Values & Information \\
\hline Customer value $\rightarrow$ Satisfaction & 0,551 & 0,000 & Poaitive Significant \\
\hline Customer trust $\rightarrow$ Satisfaction & 0,098 & 0,363 & $\begin{array}{c}\text { Positive is not } \\
\text { significant }\end{array}$ \\
\hline Customer value $\rightarrow$ Loyalty & 0,281 & 0,013 & Significant positive \\
\hline Customer trust $\rightarrow$ Loyalty & 0,338 & 0,004 & Significant positive \\
\hline Satisfaction $\rightarrow$ Customer loyalty & 0,136 & 0,203 & $\begin{array}{c}\text { Positive is not } \\
\text { significant }\end{array}$ \\
\hline
\end{tabular}

Source: Data processing with PLS, 2020

Based on the Table, it can be seen the influence and significance level of each variable, if $\mathrm{P}$ Value $<0.05$ means that the exogenous variable gives a significant influence on endogenous variables and if $\mathrm{P}$ Value $>0.05$, the exogenous variable gives no significant effect on endogenous variables with an explanation as follows:

1) Customer value has a significant positive effect on customer satisfaction at PT Samator Gas Industri Samarinda Seberang, with a coefficient value of 0.551 and a pvalue of 0,000 .

2) Customer trust has no significant positive effect on customer satisfaction at PT Samator Gas Industri Samarinda Seberang, with a coefficient value of 0.098 and a pvalue of 0.363 .

3) Customer value has a significant positive effect on loyalty at PT Samator Gas Industri Samarinda Seberang, with a coefficient value of 0.281 and a p-value of 0.013 .

4) Customer trust has a significant positive effect on loyalty to PT Samator Gas Industri Samarinda Seberang, with a coefficient value of 0.338 and a p-value of 0.004 .

5) Satisfaction has no significant positive effect on loyalty to PT Samator Gas Industri Samarinda Seberang, with a coefficient value of 0.136 and a p-value of 0.203 .

\section{Conclusions and Recommendations}

Based on the results of research and discussion that has been done, the following conclusions can be drawn:

1) Customer value has a significant positive effect on customer satisfaction at PT Samator Gas Industri Samarinda Seberang, meaning that any increase in customer value will be able to significantly increase customer satisfaction.

2) Customer trust has no significant positive effect on customer satisfaction at PT Samator Gas Industri Samarinda Seberang, meaning that any increase in customer trust will be able to increase customer satisfaction but customer value has not been able to drive an increase in satisfaction significantly.

3) Customer value has a significant positive effect on loyalty at PT Samator Gas Industri Samarinda Seberang, meaning that any increase in customer value will be able to significantly increase customer loyalty.

4) Customer trust has a significant positive effect on loyalty at PT Samator Gas Industri Samarinda Seberang, meaning that any increase in customer trust will be able to significantly increase customer loyalty.

International Journal of Economics, Business and Accounting Research (IJEBAR) Page 157 
International Journal of Economics, Business and Accounting Research (IJEBAR)

Peer Reviewed - International Journal

Vol-4, Issue-2, 2020 (IJEBAR)

E-ISSN: 2614-1280 P-ISSN 2622-4771

https://jurnal.stie-aas.ac.id/index.php/IJEBAR

5) Satisfaction has no significant positive effect on loyalty to PT Samator Gas Industri Samarinda Seberang, meaning that any increase in customer satisfaction will be able to increase customer loyalty but customer satisfaction has not been able to significantly increase customer loyalty.

Based on the conclusions stated above, it is suggested as follows:

1) In connection with the responses of respondents about customer trust, it is recommended for PT Samator Gas Industri Samarinda Seberang to strengthen the customer trust generated so that it does not disappoint consumers.

2) In connection with the responses of respondents about customer value, it is recommended that PT Samator Gas Industri Samarinda Seberang update the model, namely the variety of types and types of products sold so that the products produced always vary.

3) Given the types of products that can be produced continue to grow. it will be useful in product design, to achieve optimal results.

4) In general, customer loyalty at PT Samator Gas Industri Samarinda Seberang is already high, but it would be better if the growth of new products is enhanced by offering products with a wider variety and types and an expanded market so that this product is better known by the public so as to create loyalty. too high.

5) Conducting research by using other variables not included in this study such as price, product differentiation, promotion, location, market orientation and others to increase satisfaction and customer loyalty of PT Samator Gas Industri Samarinda Seberang.

\section{References}

Aaker David A. 2003. Brand leadership. New York: The Free Press.

Armstrong 2003. The Brand Emotional Loyalty Explaine. Emotional Loyalty: The Key to Market Succses. Jakarta. PT. Elex Media Kumputindo.

Anaroga Banner. 2004. Business Management. Third Matter. Rineka Cipta. Jakarta.

Bahar Taslim. 2009. Effect of Service Quality on User Satisfaction and Loyalty Informal Public Transport Mode. Petra Christian University Surabaya.

Baros Wan Ayesha. 2012. Contribution of Social Askes Participant's Knowledge to PT Asker's Advanced Outpatient and Inpatient Services Satisfaction in 2011. Thesis: Faculty of Public Health Master of Public Health Study Program. University of Indonesia. Jakarta.

Blair. M. Armstrong \& Murphy. 2003. The 360 degree brand in Asia. New Jersey: Prentice Hall

Cooper \& Kleinschmidt. 1987. Winning at New Products: Accelerating The Process from Idea to Launch. 2d.ed. Reading. MA: Addison-Wesley.

Dharmmestha. 1999. Customer Loyalty. First printing. Bogor. Ghalia Indonesia.

Djarwanto. PS 2001. Second Edition. Get to know some statistical tests in research. Liberti. Yogyakarta.

Eakuru Nattakarn Khamariah. Nik Mat.2008. The Application of Structural Equation Modeling (SEM) in determining The Antecedent of Customer Loyalty in Banks in South Thailand. The Business Review. Cambridge. Vol 10 (2).

Engel J. F. B. 2010. Consumer Behavior. (subtitles by Fandy Tjiptono) The Dryden Press. forth Worth. The USA.

Ferrinadewi. Erna, 2005. Brand and Consumer Psychology. Jakarta: Graha Science.

International Journal of Economics, Business and Accounting Research (IJEBAR) Page 158 
International Journal of Economics, Business and Accounting Research (IJEBAR)

Peer Reviewed - International Journal

Vol-4, Issue-2, 2020 (IJEBAR)

E-ISSN: 2614-1280 P-ISSN 2622-4771

https://jurnal.stie-aas.ac.id/index.php/IJEBAR

Fornell C. and Wernerfelt. B. 1987. Defensive Marketing Strategy by Customer Complaint Management: Theoretical Analysis. Journal of Marketing Research. Vol. November 24th. pp 337.

Ghozali. Priest. 2005. Application of Multivariate Analysis with SPSS Process. Semarang: Diponogoro University Publishing Board.

Gommans Marcel Krishnan. Krish S. \& Scheffold Katrin B. 2001. From Brand Loyalty to E-Loyalty: a Conceptual Framework. Journal of Economic and Social Research.

Haas W. Robert and Thomas R Wotruba 2008. Marketing Management Concept Practice and Case. Business Publication. Inc. Printed The United State of America.

Hadi 2002. Marketing Management. Yogyakarta. Andi Offset.

Indrianto. Nur and Supomo. Bambang. 2002. Business Research Methodology for Accounting \& Management. BPEF-YOGYAKARTA.

Irfan. S.M. Ijaz. Aamir and Farooq. M.M. 2012. Patient Satisfaction and Service Quality of Public Hospitals in Pakistan: An Empirical Assessment. Middle East Journal of Scientific Research 12 (6): 870-877. 2012.

Istijianto. 2009. Practical Application of Marketing Research (Practical Ways of researching consumers and competitors). PT. Gramedia Reader. Jakarta.

Janonis.V. Regina Virvilaite. 2007. Brand image formation. Journal of Engineering economics Volume 52. No.2.

John C. Mowen \& Michael Minor. 2002. Consumer Behavior. Jakarta. Erlangga

Jogiyanto. 2004. Business Research Methodology. BPEF-YOGYAKARTA. Yogyakarta.

Kristianto. 2011. Marketing Management Volume I. Publisher Andi. Yogyakarta.

Kotler Philip. et al. 2012. Asia Perspective Marketing Management. Book Two. First edition. Andy Yogyakarta.

Kumar Bath R.A. 2002. Experience with Consumer at Hospital in India. Journal of Marketing. Vol. 22 / No. 4

Lovelock C. 2007. Marketing Services. Australia: Prentice Hall.

Lupiyoadi. Creepers. 2007. Management of Service Marketing: Theory and Practice. First edition. Salemba Empat. Jakarta.

Nasution M.N. 2007. Integrated Quality Management. Ghalia Indonesia. Jakarta.

Nasser. Abdul and Emelin Abdul Wahid. 2006. Client Relationship Auditor. Managerial Auditing Journal. Vol 21. No. 7

Parasuraman. A. Zethamal. Valarie. Berry. Leonard 2001. "Delivering Quality Service Balancing Customer Perceptions and Expectations" The Free Press. New York.

Prahastuti. Lina. 2011. Analysis of the Effect of Service Quality and Product Quality on Consumer Satisfaction to Increase Indosat Customer Loyalty. Thesis: Faculty of Economics, Diponegoro University, Semarang. 2011

Ancient. Amir 2011. Introduction to Communication Studies. Field. National Library of Indonesia Press.

Rangkuty Fredy. 2008. Marketing Research. Third Matter. PT. Gramedia General Library. Jakarta.

Rangkuti. Freddy. 2008. The power of brands: Techniques for Managing Brand Equity and Brand Development Strategies. Jakarta: Gramedia

Riduan \& Akdon. 2009. Dalalm Formula and Data Statistical Analysis. Alfabeta. Bandung.

Saidani. Basrah \& Arifin. Samsul. 2012. The Effect of Product Quality and Service Quality on Consumer Satisfaction and Purchase Interest in the Ranch Market. Indonesian Science Management Research Journal (JRMSI) Vol. 3. No. 1. 2012.

Sarwono. Jonathan 2007. Path Analysis for Business Research with SPSS. CV. Andi offset. Yogyakarta.

International Journal of Economics, Business and Accounting Research (IJEBAR) Page 159 
International Journal of Economics, Business and Accounting Research (IJEBAR)

Peer Reviewed - International Journal

Vol-4, Issue-2, 2020 (IJEBAR)

E-ISSN: 2614-1280 P-ISSN 2622-4771

https://jurnal.stie-aas.ac.id/index.php/IJEBAR

Schiffman. Leon G and Leslie Lazar Kanuk. 2004. Customer Behavior. Prentice Hall. New Jersey.

Spreng et al. 1996. Information Process. AMA Summer Educators Conference (Paper Published as an Abstract in The Proceedings).

Stanton J. William. 2003. Fundamentals of Marketing. Fifth Edition. Tokyo: Mc. Graw Hill Book Company. Kogakusha

Swastha Basu and Irawan. 2005. Modern Marketing Management. Second Edition. Eleventh Printing. Liberty Offset. Yogyakarta.

Sugiharto. John 2007. Effect of Satisfaction on Loyalty. Vol. XVIII.

Sugiyono 2012. Combination Research Methods. Third Matter. Alfabeta. Bandung.

Sumarwan Sonny. 2003. Consumer Behavior. Theory and Application in Marketing. Jakarta. Ghalia Indonesia.

Surjandari. Isti and Susetiana. Harmawan. 2009. Analysis of Customer Loyalty in the Airfreight Forwarder Industry Using Structural Equation Modeling (SEM). Proceeding on the National Seminar on Industrial Engineering \& Production Management IV. Surabaya.

Syriac. T. 1998. Strategic Value of Customer Loyalty: Development of Concepts and Management Implications. Business No. 09 TH XXVII. September 1998.

System. et al. 2000. Strategic and Operational Management with Optimization. McGrawHill. New York.

Terry R. George. 2009. Principle of Management. Sevent Edition. Home Wood illions. Richard d Irwin Inc.

Tjiptono. Fandy 2008. Service Management: Realizing Excellent Service. Yogyakarta: Andi Publisher

Tse Wilton. 2009. Marketing Research: An Applied Orientation. Prentice Hall. New Jersey.

Umar 2003. Research Methods. For Thesis and Business Thesis. Rajawali Press. Jakarta.

V. Mital. WT. Ross and PM. Baldasare. 1998. Asymmetric Impact of Negative and Positive Level. Anderson. The USA

Walker Orville. Jr. Boyd Harper W. Jr. Mullins. John Larreche. Jean Claude. Strategy A Decision: Focused Approach. 4th edition of McGraw Hill. Boston.

Wilkie. William L. 1994. Consumer Behavior. New York: Third Edition. Jhon Wiley \& Sons Inc.

Winardi. 2008. Indonesian English Economic Dictionary. Bandung Alumni. Bandung.

Wijayanti. MP. 2008. Auditor Client Relationship Analysis. Thesis of the Faculty of Economics, Diponegoro University. 